Article

JAVAID, A. ${ }^{1 *}$

AFZAL, L. ${ }^{1}$

SHOAIB, A. ${ }^{1}$

\section{Antifungal Potential of a Brassicaceous Weed Sisymbrium irio AGAINST Macrophomina phaseolina}

\section{Potencial Antifúngico da Planta Daninha Brassicácea Sisymbrium irio Diante de Macrophomina phaseolina}

\begin{abstract}
Macrophomina phaseolina, a soil-borne plant pathogen, has the ability to cause diseases in about 500 plant species. Unfortunately, so far no registered fungicide is available against this fungal pathogen. In the present study, different extracts of Sisymbrium irio, a weed of family Brassicaceae, were tested for evaluation of their antifungal activity against M. phaseolina. In screening bioassays, antifungal activity of methanolic extracts of $1 \%$ to $6 \%$ concentrations of different parts (leaf, stem, root and fruit) of the weed was assessed against the fungal pathogen. Methanolic leaf and root extracts significantly reduced fungal biomass up to $59 \%$ and $69 \%$ over control, respectively. Methanolic leaf and root extracts were further partitioned using four organic solvents namely $n$-hexane, chloroform, ethyl acetate and $n$-butanol in order of increasing polarity. Antifungal activity of different concentrations of these fractions $\left(3.125,6.25, \ldots, 200 \mathrm{mg} \mathrm{mL}^{-1}\right)$ was assessed against the pathogen. Chloroform and $n$-hexane fractions of methanolic leaf extract showed highly pronounced activity resulting in $35-75 \%$ and $15-87 \%$ reduction in fungal biomass over corresponding control treatments, respectively. Likewise, the highest concentration $\left(200 \mathrm{mg} \mathrm{mL}^{-1}\right)$ of chloroform, ethyl acetate and $n$-butanol fractions of methanolic root extract reduced fungal biomass by $75 \%, 70 \%$ and $87 \%$, respectively. The present study concludes that chloroform and $n$-butanol fractions of methanolic leaf and root extracts of S. irio, respectively, contain potent antifungal constituents for management of M. phaseolina.
\end{abstract}

Keywords: antifungal activity, London rocket, plant extracts.

RESUMO - Macrophomina phaseolina, um patógeno vegetal do solo, tem a capacidade de causar doenças em cerca de 500 espécies de plantas. Infelizmente, até agora nenhum fungicida registrado foi disponibilizado contra esse patógeno fúngico. No presente estudo, diferentes extratos de Sisymbrium irio, uma planta daninha da familia Brassicácea, foram testados para avaliação de sua atividade antifúngica contra M. phaseolina. Em bioensaios de triagem, a atividade antifúngica de extratos metanólicos de concentrações de 1\% a 6\% de diferentes partes (folha, caule, raiz e fruta) da planta daninha foi avaliada contra o patógeno fúngico. Os extratos metanólicos de folhas e raizes reduziram significativamente a biomassa fúngica em até $59 \%$ e $69 \%$ acima do controle, respectivamente. Os extratos metanólicos de folha e de raiz foram divididos utilizando quatro solventes orgânicos: n-hexano, clorofórmio, acetato de etilo e n-butanol, em ordem de polaridade crescente. A atividade antifúngica de diferentes concentrações dessas frações $\left(3,125,6,25, \ldots, 200 \mathrm{mg} \mathrm{mL}^{-1}\right)$ foi avaliada contra o patógeno. As frações de clorofórmio e n hexano do extrato metanólico de folha mostraram uma atividade

1 Institute of Agricultural Sciences, University of the Punjab, Lahore, Pakistan.

Planta Daninha 2017; v35:e017164280

* Corresponding author:

<arshadjpk@yahoo.com>

Received: May 11,2016

Approved: June 30, 2016 
altamente pronunciada, resultando em $35-75 \%$ e $15-87 \%$ de redução da biomassa fúngica em relação aos tratamentos de controle correspondentes, respectivamente. Da mesma forma, a maior concentração (200 $\mathrm{mg} \mathrm{mL}^{-1}$ ) de frações de clorofórmio, acetato de etilo e n-butanol de extrato metanólico de raiz reduziu a biomassa fúngica em $75 \%, 70 \%$ e $87 \%$, respectivamente. O presente estudo conclui que as frações de clorofórmio e n-butanol de extratos metanólicos de folhas e raizes de $\boldsymbol{S}$. irio, respectivamente, contêm potentes componentes antifúngicos para o manejo de M. phaseolina.

Palavras-chave: atividade antifúngica, London rocket, extratos vegetais.

\section{INTRODUCTION}

Macrophomina phaseolina is one of the most destructive soil-borne Ascomycetous fungus of family Botryosphaeriaceae that is devoid of a sexual stage. Under favorable environmental conditions, the fungus causes charcoal rot, dry rot, stem blight, leaf blight and damping off in more than 500 plant species belonging to about 100 angiospermic families (Ijaz et al., 2013). Cereals, legumes, oil seed crops, horticultural crops as well as woody plants could not escape from this devastating pathogen (Ijaz et al., 2013; Yildiz and Benlioglu, 2014; Sun et al., 2016). It primarily infects its host plants through black and multi-celled (50 to 200 individual cells) microsclerotia which are hyphal cells aggregates formed by joining melanin material (Holliday, 1995). Microsclerotia may plug the vascular vessels with consequences in plant wilting (Islam et al., 2012). When the infected plant is decayed, the microsclerotia are carried to the soil and persist there for more than three years (Dhinga and Sinclair, 1977). Infected plant debris in soil gives microsclerotia a survival home (Holliday, 1995). Sclerotia can bear a temperature above $30{ }^{\circ} \mathrm{C}$ in dry soil and under wet conditions mycelium hardly survives over 7 days and the sclerotia survival period is not exceeded over 2 months (Premamalinia et al., 2012). Adaptation of M. phaseolina to a broad range of osmotic and $\mathrm{pH}$ is due to the higher content of a distinct set of carbohydrate esterases (Islam et al., 2012). This aggressive pathogen is hard to manage through cultural or chemical options (Afouda et al., 2012) and a biological strategy could be effective through exploring the role of indigenous plants (Javaid et al., 2015).

Brassicaceae is one of the largest angiosperm families distributed all over the world with 338 genera and more than 3,709 species (Al-Shehbaz et al., 2006). London rocket (Sisymbrium irio) is an annual winter weed of family Brassicaceae, native to northern Africa. It grows along roadsides, fence and ditches in Punjab, Pakistan. It is also recognized with other names like desert mustard, rocket mustard etc. and produces many small flowers, self-compatible, self-pollinated, and disseminates through seeds (Wilkin and Hannah, 1998). The nutritional composition of this species, including protein, fat, and carbohydrate and minerals, is considered to be beneficial as forage (Shehata, 2014). This weed has significance as folk medicinal plant due to its antimicrobial, analgesic, antipyretic and antioxidant potential (Lev, 2003; Al-Jaber, 2011). The phytochemical assessment of the weed has revealed that it is comprised of many secondary metabolites like flavonoids, alkaloids, oils, and glucosinolates (Khan et al., 1991; AlQudah and Abu Zarga, 2010; Shah et al., 2013). Previous literature has confirmed the antimicrobial activity of phenolic and flavonoid compounds of Brassicaeous plants (Mothana and Lindequist, 2005; Song et al., 2007; Grosso et al., 2011). However, S. irio has rarely been explored for its antifungal activity. The present study was therefore carried out to investigate the antifungal activity of methanolic extracts of different parts of this weed against $M$. phaseolina.

\section{MATERIALS AND METHODS}

\section{Screening bioassays}

Two hundred grams of thoroughly crushed materials of each part viz. leaf, stem, fruit and root of $S$. irio were soaked in $1,000 \mathrm{~mL}$ methanol separately in air tight jars for 14 days. Cheese cloth followed by qualitative filter paper were used to filter soaked materials, and solvent was removed on a rotary evaporator at $45{ }^{\circ} \mathrm{C}$ under reduced pressure. For a complete evaporation of 
the solvent, each extract was poured in $100 \mathrm{~mL}$ beaker and finally a thick paste of $14.29 \mathrm{~g}, 10 \mathrm{~g}$, $11 \mathrm{~g}$ and $10.87 \mathrm{~g}$ leaf, stem, root and fruit extracts, respectively, was obtained (Javaid and Akhtar, 2015).

Methanolic extract (9.45 g) of each of the four plant parts was dissolved in $6 \mathrm{~mL}$ Dimethyl sulphoxide (DMSO) and a final volume $(21 \mathrm{~mL})$ was raised by distilled autoclaved water to prepare stock solutions. Similarly, a control solution was prepared by adding $6 \mathrm{~mL}$ DMSO in $15 \mathrm{~mL}$ distilled water. For each treatment, $74 \mathrm{~mL}$ malt extract (ME) were autoclaved in a $250 \mathrm{~mL}$ volume flask and cooled at room temperature. Six concentrations viz. $1,2, \ldots .6 \%$ were prepared by adding 1,2 , 3, 4, 5 and $6 \mathrm{~mL}$ of stock solution with $5,4,3,2,1$ and $0 \mathrm{~mL}$ of the control solution, respectively, to raise the volume of the medium in $80 \mathrm{~mL}$ in each flask. This volume was divided into four equal parts in $100 \mathrm{~mL}$ flasks. To prepare the control treatment, $6 \mathrm{~mL}$ of the control solution were mixed with $74 \mathrm{~mL}$ of malt extract to maintain the same quantity of DMSO in all the treatments, and divided into four equal parts of $20 \mathrm{~mL}$ each to serve as replicates. Mycelial discs of M. phaseolina were prepared from the tips of 7 days old fungal culture by using a sterilized $5 \mathrm{~mm}$ diameter cork borer and one disk was transferred to each flask. Flasks were incubated at $27 \pm 1{ }^{\circ} \mathrm{C}$ for 7 days. After the incubation period, pre-weighed filter papers were used to filter the fungal biomass and a dried biomass was obtained by drying it at $60{ }^{\circ} \mathrm{C}$ (Javaid and Akhtar, 2015).

\section{Fractionation of methanolic leaf and root extracts}

Two kilograms of dried and powdered leaves and one kilogram of roots were extracted with methanol $(2 \times 7 \mathrm{~L})$ at room temperature for two weeks. Following filtration, a dried crude methanolic extract of leaf and root was obtained by evaporating the solvent on a rotary evaporator.

The crude methanolic leaf extract was suspended in water $(200 \mathrm{~mL})$ in a separatory funnel and extracted with $n$-hexane $(500 \mathrm{~mL})$ until whole $n$-hexane soluble compounds from the mixture were separated. $n$-hexane phase was evaporated under vacuum and a $9.1 \mathrm{~g}$ dried fraction was collected. Afterward, a successive extraction of residual extract was done with chloroform $(500 \mathrm{~mL})$, ethyl acetate $(500 \mathrm{~mL})$, and $n$ butanol $(500 \mathrm{~mL})$ and yield of $24.3 \mathrm{~g}, 1.9 \mathrm{~g}$ and $6.2 \mathrm{~g}$ of chloroform, ethyl acetate and $n$-butanol fraction, respectively, were achieved. The leftover aqueous extract was evaporated and $19.7 \mathrm{~g}$ of this fraction were obtained (Javaid and Rauf, 2015).

The crude methanolic root extract was dissolved in $200 \mathrm{~mL}$ water and fractionated by successive solvent extractions with $n$-hexane $(500 \mathrm{~mL}$ several times), chloroform (500 mL), ethyl acetate $(500 \mathrm{~mL})$ and $n$-butanol $(500 \mathrm{~mL})$, respectively, to yield $n$-hexane fraction $(4.1 \mathrm{~g})$, chloroform fraction $(2.7 \mathrm{~g})$, ethyl acetate fraction $(3.0 \mathrm{~g}), n$-butanol fraction $(2.5 \mathrm{~g})$, and aqueous fraction $(3.2 \mathrm{~g})$.

\section{Bioassays with fractions of methanolic extracts}

In vitro, antifungal activity of various fractions from methanolic leaf and root extracts were assessed against $M$. phaseolina. A stock solution of $200 \mathrm{mg} \mathrm{mL}^{-1}$ was prepared by homogenizing $1.2 \mathrm{~g}$ of each fraction of methanolic leaf and root extracts in $1 \mathrm{~mL}$ DMSO and $5 \mathrm{~mL}$ of ME broth. Lower-grades of $100,50,25,12.5,6.25$, and $3.125 \mathrm{mg} \mathrm{mL}^{-1}$ were prepared by adding ME broth. To make a control set parallel to various extract concentrations, a serial double dilution was done after dissolving $1 \mathrm{~mL}$ of DMSO in $5 \mathrm{~mL}$ malt extract broth. Antifungal assays were performed in $10 \mathrm{~mL}$ glass test tubes, each filled with $1 \mathrm{~mL}$ of the growth medium. Inoculum of $M$. phaseolina was prepared in distilled water and $10 \mu \mathrm{L}$ of this inoculum were added to each test tube and these were incubated at room temperature. A triad set of each treatment was maintained. After 7 days, fungal biomass in each test tube was filtered, dried and weighed (Javaid and Rauf, 2015).

\section{Statistical analysis}

All the data were analyzed by analysis of variance (ANOVA) followed by the LSD method ( $\mathrm{P} \leq 0.05)$ using computer software Statistix 8.1. 


\section{RESULTS AND DISCUSSION}

\section{Screening bioassays}

Analysis of variance (ANOVA) revealed that the effect of different plant parts of S. irio (P), extract concentration $(\mathrm{C})$ as well the interactive effect of $\mathrm{P} \times \mathrm{C}$ were significant for biomass of M. phaseolina (Table 1).

Data regarding the effect of methanolic extract of different parts of S. irio on biomass of M. phaseolina is presented in Figure 1. There was a great variability in antifungal activity among extracts of different parts of the test plant species. In case of leaf extract, maximum fungal biomass $(120 \mathrm{mg})$ was recorded in the lower most extract concentration, i.e., $1 \%$ that was significantly greater than fungal biomass in control by $23 \%$. By contrast, all other extract concentrations variably reduced fungal biomass by $6-59 \%$. There was a gradual reduction in fungal biomass due to an increase in the extract concentration from $2 \%$ to $6 \%$. An adverse effect of 3-6\% concentrations on fungal biomass was significant as compared to control. Likewise, all the concentrations of root extract except 1\% significantly reduced fungal biomass by $31-69 \%$. An inhibitory effect of the extract was concentration dependant. In contrast, both stem and fruit extracts stimulated the fungal growth to variable extents. Different concentrations of stem and fruit extracts enhanced the fungal biomass by $59-64 \%$ and $13-51 \%$, respectively. Generally, lower concentrations (1-5\%) were more stimulatory than the highest concentration (6\%). There are many similar examples in the literature supporting the findings of the present study

Table 1 - Analysis of variance (ANOVA) for the effect of different concentrations of methanolic leaf, stem, root and fruit extracts of Sisymbrium irio on biomass of Macrophomina phaseolina

\begin{tabular}{|l|r|r|r|r|}
\hline \multicolumn{1}{|c|}{ Sources of variation } & df & SS & MS & F values \\
\hline Treatments & 27 & 189468 & 7017 & $73^{*}$ \\
\hline Plant parts (P) & 3 & 130218 & 43405 & $450^{*}$ \\
\hline Concentration (C) & 6 & 26480 & 4413 & $46^{*}$ \\
\hline P x C & 18 & 32769 & 1820 & $19 *$ \\
\hline Error & 111 & 197567 & & \\
\hline Total & & & \\
\hline
\end{tabular}

* Significant at $\mathrm{P} \leq 0.001$

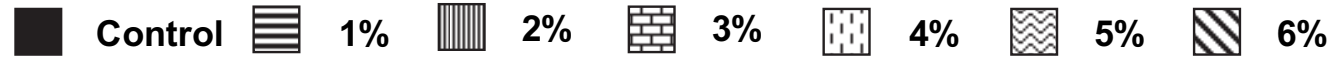

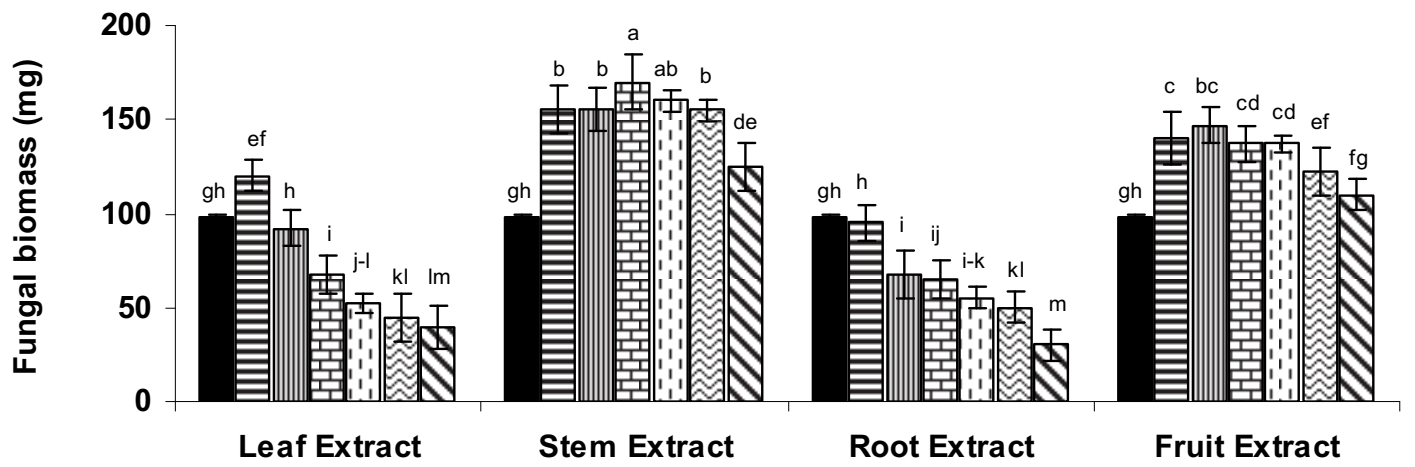

Vertical bars show standard errors of means of three replicates. Values with different letters at their top show significant difference (P $\leq 0.05$ ) as LSD Test.

Figure 1 - Effect of different concentrations of methanol leaf, stem, root and fruit extracts of Sisymbrium irio on biomass of Macrophomina phaseolina. 
(Carpinella et al., 2003; Singh et al., 2009; Javaid et al., 2015). Variation in antifungal activity may be attributed to different quantities of effective antifungal constituents or the presence of different types of compounds in different plant parts (Rauf and Javaid, 2013). A similar variability in antifungal activity among plant parts has also been demonstrated in Datura metel, Coronopus didymus and Imperata cylindrica against Fusarium oxysporum, Macrophomina phaseolina and Sclerotium rolfsii (Iqbal and Javaid, 2012; Javaid and Saddique, 2012; Javaid et al., 2015).

\section{Bioassays with fractions of methanolic leaf extract}

DMSO used for dissolving various fractions of methanolic leaf extract also inhibited the fungal growth and its effect was increased with increasing concentrations (Figure 2). Fungal biomass varied from $20 \mathrm{mg}$ to $54 \mathrm{mg}$ in different concentrations of DMSO in control. A similar inhibitory effect of DMSO has also been reported against other fungal species, namely Alternaria alternata, Fusarium oxysporum and Ascochyta rabiei (Javaid and Samad, 2012; Javaid and Munir, 2012; Javaid and Rauf, 2015). All the concentrations of $n$-hexane, chloroform and ethyl acetate fractions reduced the fungal biomass to variable extents with respect to the corresponding control treatments having the same concentration of DMSO in the growth medium. The effect of lower concentrations (3.125-12.5 $\mathrm{mg} \mathrm{mL}^{-1}$ ) of $n$-hexane fraction was less pronounced with $15-20 \%$ reduction in fungal biomass over the respective control treatments. Higher concentrations of this fraction $\left(25-200 \mathrm{mg} \mathrm{mL}^{-1}\right)$ were much more inhibitory, resulting in $67-87 \%$ reduction in fungal biomass over control (Figure 2A). The adverse effect of different concentrations of chloroform fraction was generally significant $(\mathrm{P} \leq 0.05)$ where $35-75 \%$ reduction in fungal biomass over control was recorded (Figure 2B). The antifungal activity pattern of different concentrations of ethyl acetate fraction was similar to that of chloroform fraction. However, this fraction was comparatively less effective against $M$. phaseolina as compared to chloroform fraction. There was a 35-75\% reduction in fungal biomass over control due to different grades of ethyl acetate fraction of leaf extract (Figure 2C). By contrast, all the grades of $n$-butanol fraction except the lower most one $\left(3.125 \mathrm{mg} \mathrm{mL}^{-1}\right)$ variably stimulated the fungal growth, resulting in an enhanced fungal biomass over control. The effect of lower concentrations $\left(6.25-25 \mathrm{mg} \mathrm{mL}^{-1}\right)$ was insignificant where a $10-38 \%$ increase in fungal biomass over control was recorded. On the other hand, higher concentrations $\left(50-200 \mathrm{mg} \mathrm{mL}^{-1}\right)$ significantly $(\mathrm{P} \leq 0.05)$ enhanced the fungal biomass by $43-48 \%$ over the corresponding control treatments (Figure 2D). The highest extract concentration $\left(200 \mathrm{mg} \mathrm{mL}^{-1}\right)$ of aqueous fraction significantly $(\mathrm{P} \leq 0.05)$ reduced fungal biomass by $70 \%$ over the corresponding control treatment (Figure 2E). A similar variable antifungal potential of different organic solvent fractions of methanolic extracts of WIthania somnifera, C. didymus, Chenopodium album and $D$. metel has also been reported against $S$. rolfsii, A. rabiei, $F$. oxysporum f. sp. cepae and M. phaseolina (Iqbal and Javaid, 2012; Javaid and Munir, 2012; Javaid and Saddique, 2012; Rauf and Javaid, 2013). This possibly happened because of dissimilar polarity compounds in various organic solvents with different antifungal activities.

\section{Bioassays with fractions of methanolic root extract}

The antifungal activity of different fractions of methanolic root extract of S. irio against M. phaseolina was less pronounced than the corresponding fractions of leaf extract. In general, lower concentrations (3.125-100 $\mathrm{mg} \mathrm{mL}^{-1}$ ) either stimulated or showed an insignificant effect on fungal growth. Conversely, the highest concentration $\left(200 \mathrm{mg} \mathrm{mL}^{-1}\right)$ of all the fractions of methanolic root extract exhibited a significant $(\mathrm{P} \leq 0.05)$ adverse effect on fungal growth. There was a $41 \%, 75 \%, 70 \%, 87 \%$ and $54 \%$ reduction in fungal biomass due to $200 \mathrm{mg} \mathrm{mL}^{-1}$ concentration of $n$-hexane, chloroform, ethyl acetate, $n$ butanol and aqueous fraction of methanolic root extract, respectively (Figure 3A-E). The production of glucosinolates by the Brassicacious plants has already been explored (Sun et al., 2011) and the potential of such compounds has been suggested against different fungal pathogens (Al-Gendy et al., 2010). In addition, flavonoides present in S. irio (Khan et al., 1991; Al-Qudah and Abu Zarga, 2010), may also be responsible for antifungal activity against $M$. phaseolina (Kanwal et al., 2010).

The present study concludes that root and leaf extracts of $S$. irio contain potent antifungal constituents for the management of $M$. phaseolina. Further studies are required to identify 

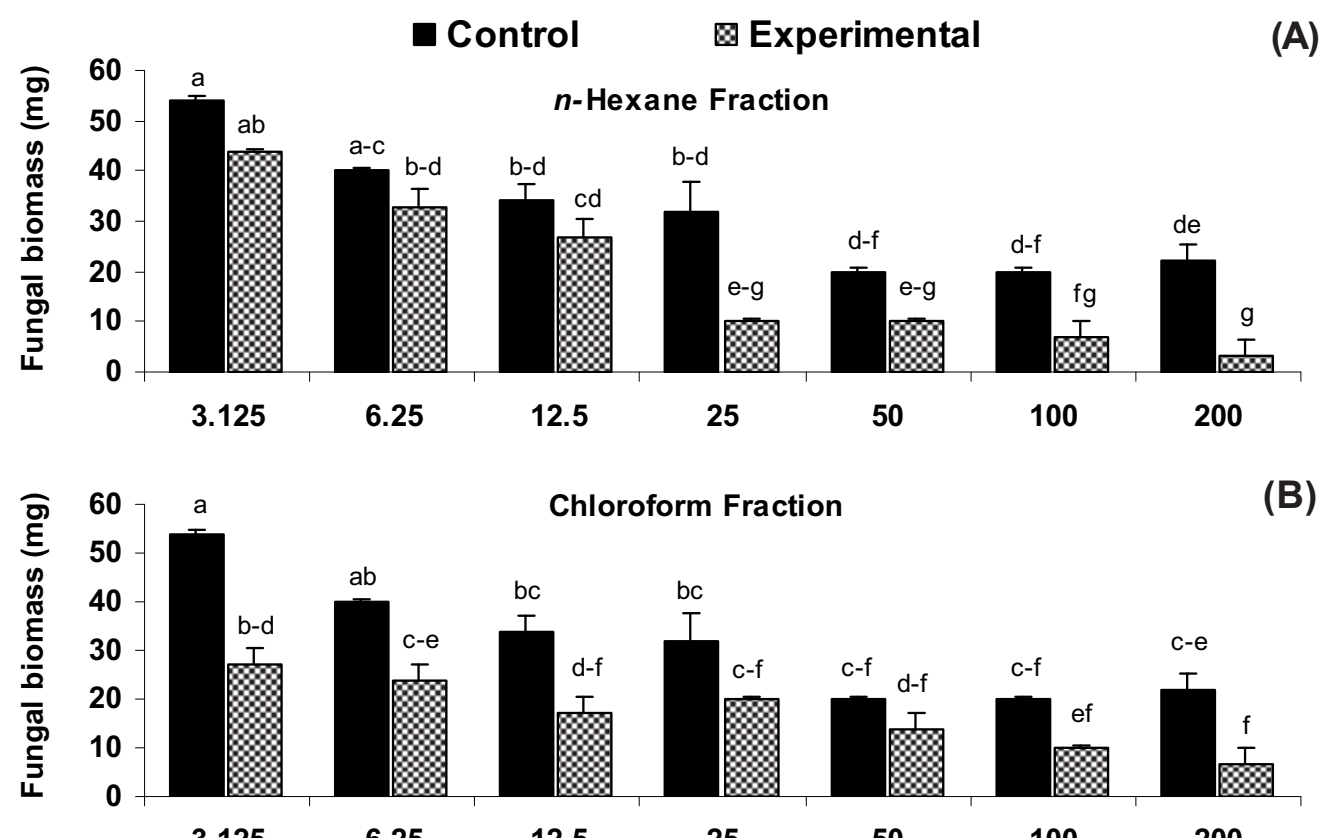

Chloroform Fraction

(B)

3.125
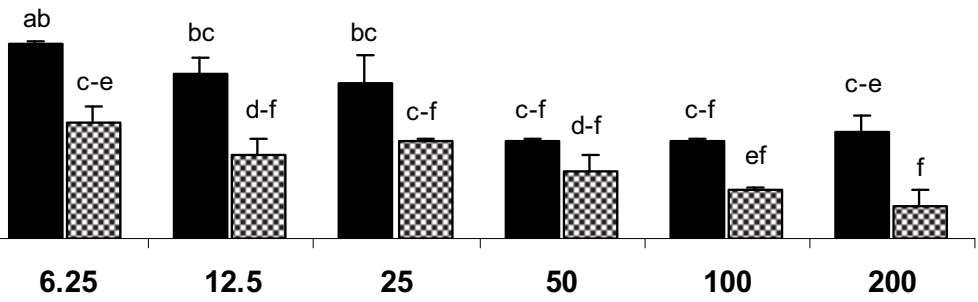

12.5

25

50

(C)

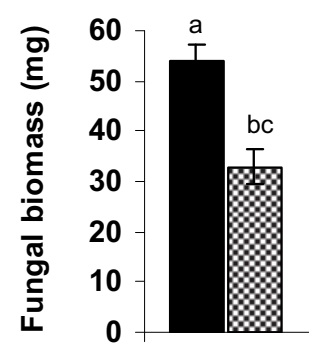

Ethyl Acetate Fraction

(A)

3.125

$\mathrm{ab}$

$\mathrm{ab}$
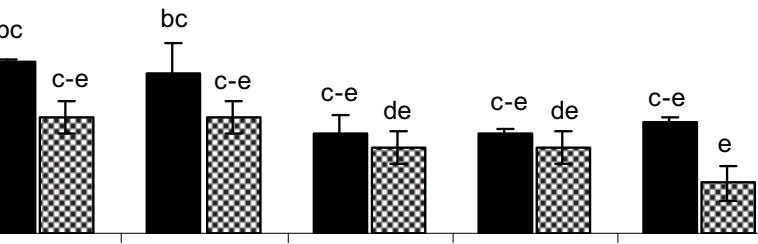

25

50

100

200

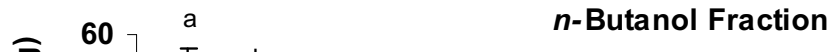

(D)
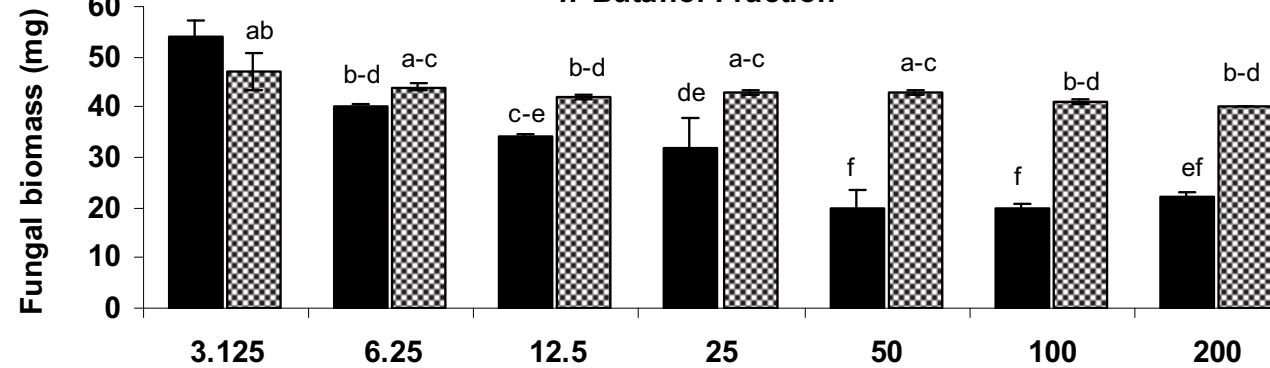

3.125

6.25

12.5

25

50

100

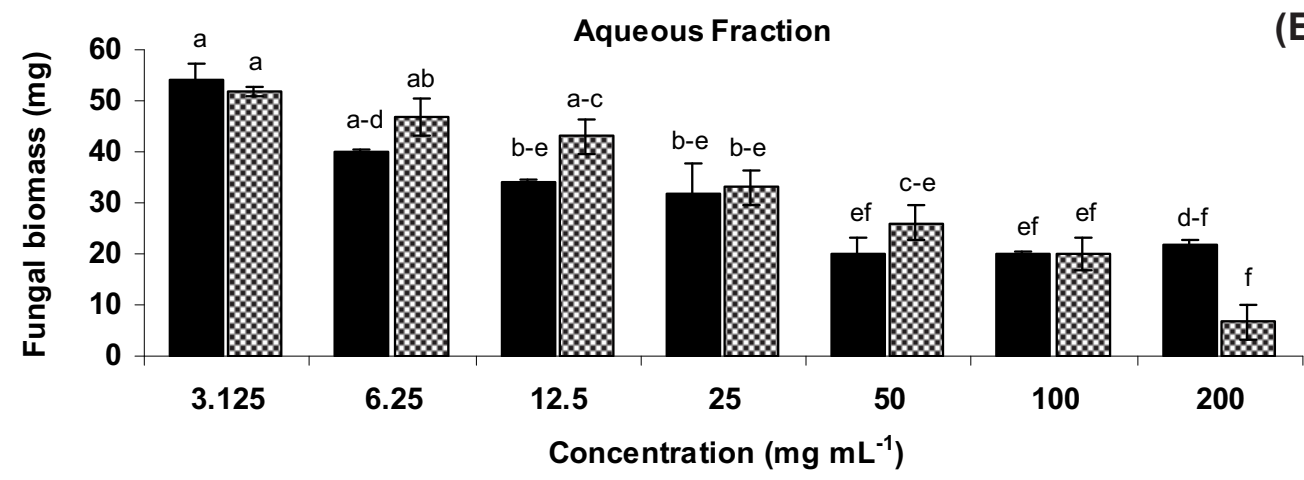

(E)

Values with different letters show a significant difference $(\mathrm{P} \leq 0.05)$ as determined by the LSD Test.

Figure 2 - Effect of different concentrations of $n$-hexane, chloroform, ethyl acetate, $n$ butanol and aqueous fraction of methanolic leaf extract of Sisymbrium irio on growth of Macrophomina phaseolina. 

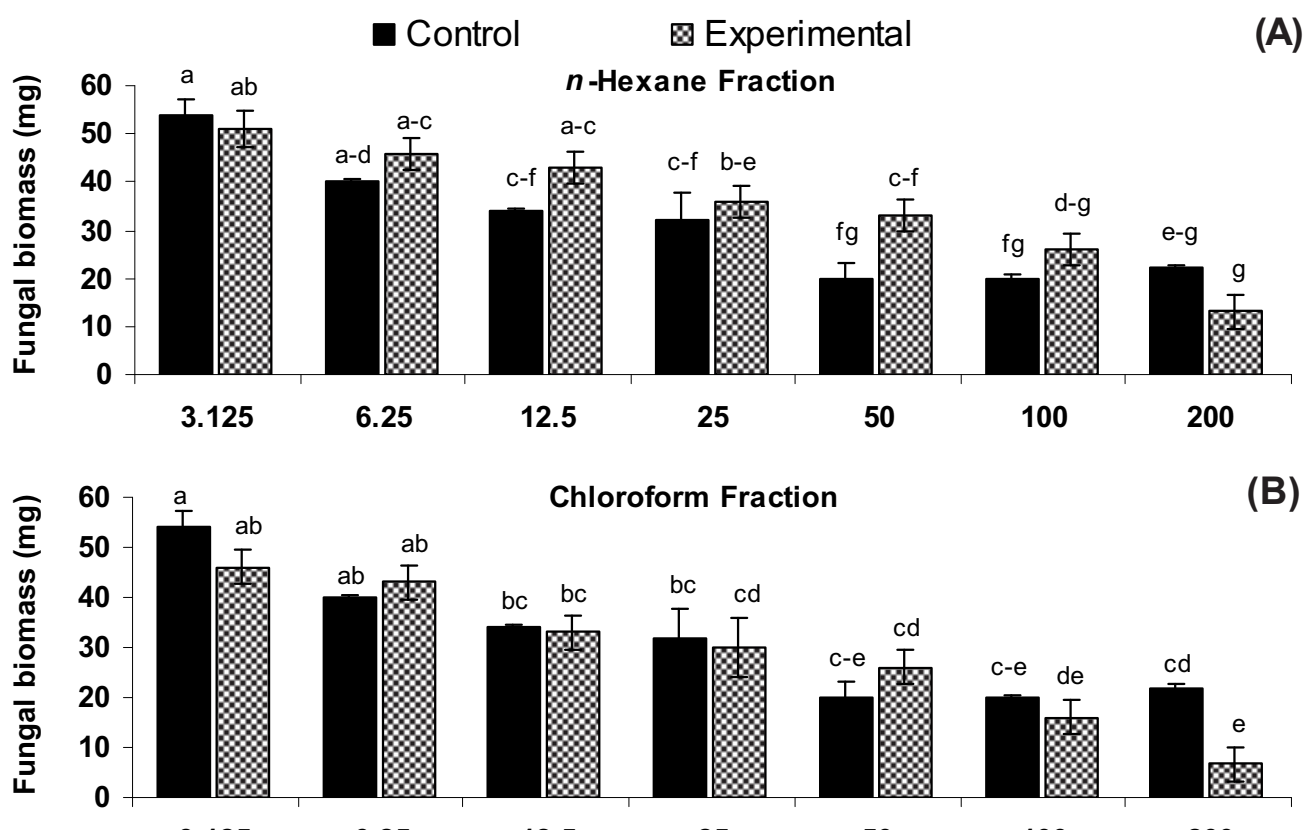

Chloroform Fraction

(B)

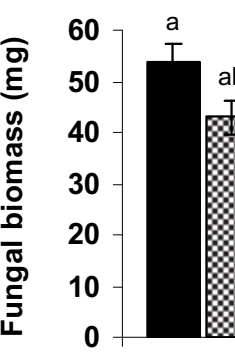

Ethyl Acetate Fraction

(C)

3.125

6.25
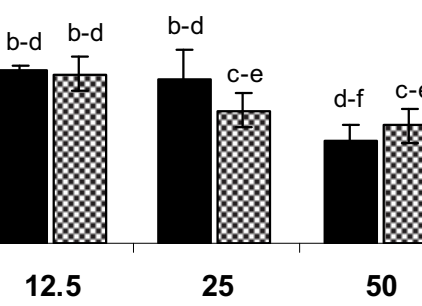

50

(D)
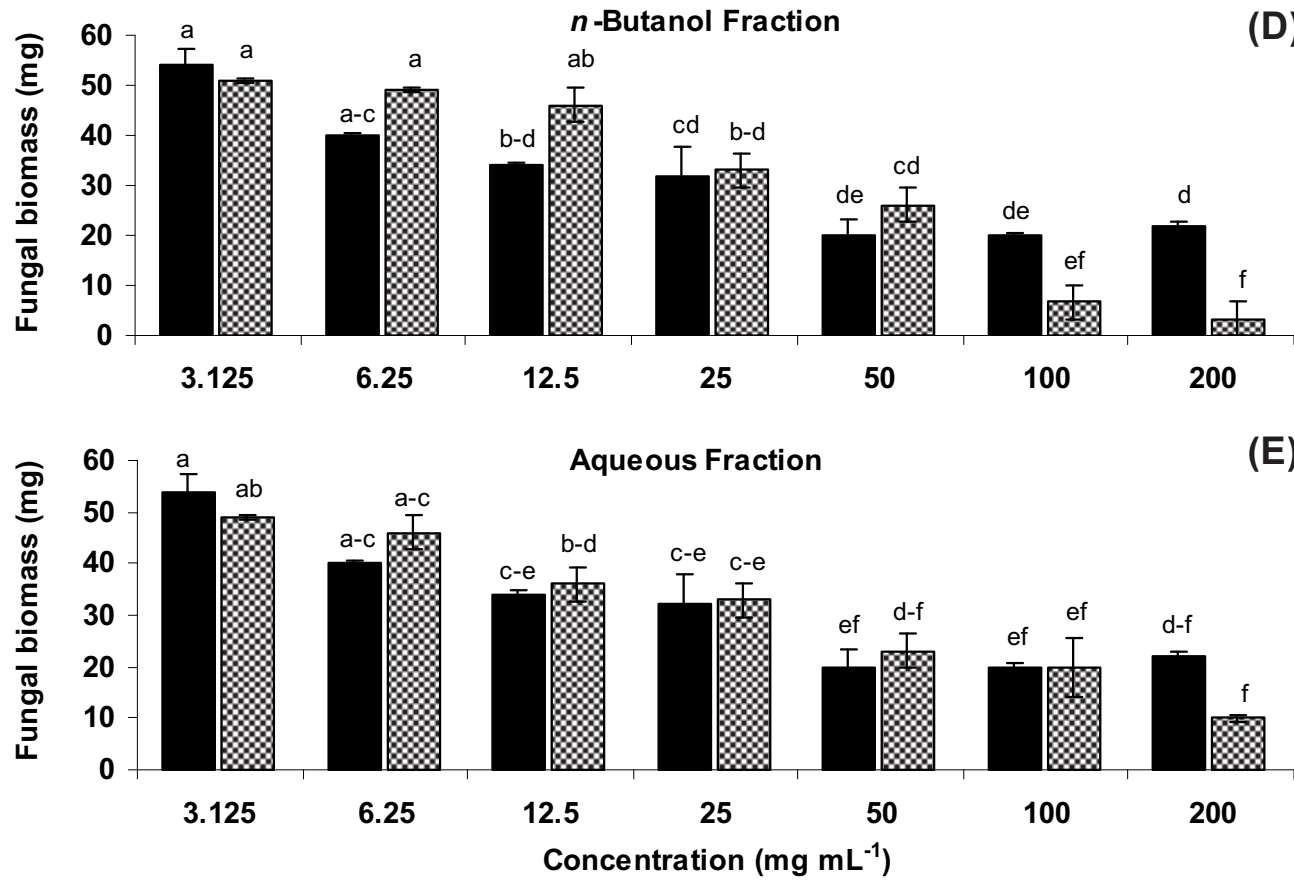

Values with different letters show a significant difference $(\mathrm{P} \leq 0.05)$ as determined by the LSD Test.

Figure 3 - Effect of different concentrations of $n$-hexane, chloroform, ethyl acetate, $n$ butanol and aqueous fraction of methanolic root extract of Sisymbrium irio on growth of Macrophomina phaseolina. 
effective antifungal constituents from chloroform and $n$-butaol fractions of methanolic leaf and root extracts of $S$. irio, respectively.

\section{REFERENCES}

Afouda L.C.A. et al. Biological control of Macrophomina phaseolina on cowpea (Vigna unguiculata) under dry conditions by bacterial antagonists. Int J Biol Chem Sci. 2012;6:5068-77.

Al-Jaber N.A. Phytochemical and biological studies of Sisymbrium irio L. Growing in Saudi Arabia. J Saudi Chem Soc. 2011;15:345-50.

Al-Gendy A.A. et al. Glucosinolates, volatile constituents and biological activities of Erysimum corinthium Boiss. (Brassicaceae). Food Chem. 2010;118:519-24.

Al-Qudah M.A., Abu Zarga M.H. Chemical composition of essential oils from aerial parts of Sisymbrium irio from Jordan. J Chem. 2010;7:6-10.

Al-Shehbaz I.A., Beilstein M.A., Kellogg E.A. Systematics and phylogeny of the Brassicaceae (Cruciferae): An overview. Plant Syst Evol. 2006;259:89-120.

Carpinella H. et al. Antifungal effects of different organic extracts from Melia azedarach L. on phytopathogenic fungi and their isolated active components. J Agric Food Chem. 2003;51:2506-11.

Dhinga O.D., Sinclair J.B. An annotated bibliography of Macrophomina phaseolina 1905-1975. Viçosa, MG: Universidade Federal de Vicosa, 1977.

Grosso C. et al. Chemical composition and biological screening of Capsella bursa-pastoris. Rev Bras Farmac. 2011;21:635-43.

Holliday P. Fungus diseases of tropical crops. New York: Dover Publications, 1995. p.254-5.

Ijaz S., Sadaqat H.A., Khan M.N. A review of the impact of charcoal rot (Macrophomina phaseolina) on sunflower. J Agric Sci. 2013;151:222-7.2013.

Iqbal D., Javaid A. Bioassays guided fractionation of Coronopus didymus for its antifungal activity against Sclerotium rolfsii. Nat Prod Res. 2012;26:1638-44.

Islam M.S. et al. Tools to kill: genome of one of the most destructive plant pathogenic fungi Macrophomina phaseolina. BMC Genomics. 2012;13:1-16.

Javaid A., Munir R. Bioassay guided fractionation of Withania somnifera for the management of chickpea blight pathogen Ascochyta rabiei. Int J Agric Biol. 2012;14:797-800.

Javaid A., Saddique A. Control of charcoal rot fungus Macrophomina phaseolina by extracts of Datura metel. Nat Prod Res. 2012;26:1715-20

Javaid A., Samad S. Screening of allelopathic trees for their antifungal potential against Alternaria alternata strains isolated from dying back Eucalyptus spp. Nat Prod Res. 2012;26:1697-702.

Javaid A., Akhtar R. Antifungal activity of methanolic root extract of Withania sommnifera against Fusarium oxysporum f. sp. cepae. Afr J Trad Complement Altern Med. 2015;12:22-7.

Javaid A., Rauf S. Management of basal rot disease of onion with dry leaf biomass of Chenopodium album as soil amendment. Int J Agric Biol. 2015; 17:142-8.

Javaid A. et al. Management of Macrophomina phaseolina by extracts of an allelopathic grass Imperata cylindrica. Pak J Agric Sci. $2015 ; 15: 37-41$.

Kanwal Q. et al. Antifungal activity of flavonoids isolated from mango (Mangifera indica L.) leaves. Nat Prod Res. 2010;24:1907-14.

Khan M.S.Y., Javed K., Khan M. Chemical constituents of the aerial parts of Sisymbrium irio. J Indian Chem Soc. 1991;68:532. 
Lev F. "Sisymbrium irio" Medicinal substances in Jerusalem from early times to the present day Archaeopress. Oxford: 2003. 62p.

Mothana A.A.R., Lindequist U. Antimicrobial activity of some medicinal plants of the island Soqotra. J Ethnopharmacol. 2005;96:177-81.

Premamalinia T. et al. Fungal keratitis caused by Macrophomina phaseolina - A case report. Med Mycol Case Rep. 2012;1:123-6.

Rauf S., Javaid A. Antifungal activity of different extracts of Chenopodium album against Fusarium oxysporum f. sp. cepae the cause of onion basal rot. Int J Agric Biol. 2013;15:367-71.

Shah S. et al. Pharmacognostic standardization and pharmacological study of Sisymbrium irio L. Am J Res Comm. 2013;1:241-53.

Shehata H.F.S. Ecology and nutritive status of Sisymbrium irio L. in the Nile delta, Egypt. Egypt J Exp Biol. 2011;10:127-42.

Singh K. et al. Phenolic acid analysis and biological activity of methanolic extracts of some medicinal plants against some phytopathogenic fungi. Int J Alt Med. 2009;6:10-20.

Song N. et al. Several flavonoids from Capsella bursa-pastoris (L.) Medik. Asian J. Tradit Med. 2007;2:218-22.

Sun B. et al. Variation of glucosinolates in three edible parts of Chinese kale (Brassica alboglabra Bailey) varieties. Food Chem. 2011;124:941-7.

Sun S. et al. Occurrence of charcoal rot caused by Macrophomina phaseolina, an emerging disease of adzuki bean in China. J Phytopathol. 2016;164:212-6.

Wilkin D., Hannah L. Sisymbrium irio (Brassicaceae) London Rocket. Santa Barbara: Botanic Garden for Channel Islands National Park, 1998.

Yildiz A., Benlioglu S. Macrophomina phaseolina and Rhizoctonia solani isolates to strawberry stolons. Phytoparasitica. 2014;42:367-9. 